\title{
Precocious puberty in children
}

\author{
Irum Atta*, Taj Muhammad laghari, Yasir Naqi Khan, Saira Waqar Lone, Mohsina Ibrahim, Jamal Raza \\ From 7th APPES Biennial Scientific Meeting \\ Nusa Dua, Bali. 14-17 November 2012
}

\section{Objective}

To determine the etiology of precocious puberty at tertiary care hospital and to compare the clinical and laboratory parameters of central and peripheral precocious puberty.

\section{Study design}

Cross sectional study.

\section{Place and duration of study}

Endocrine clinic at National Institute of child health, Karachi, Pakistan from January 2009 to December 2011.

\section{Methodology}

Children who fulfilled the criteria of precocious puberty were included. Precocious puberty defined as the development of secondary sexual characteristics before the age of 8 years in girls and 9 years in boys. All patients evaluated clinically and on laboratory investigations. Data was entered and analyzed using SPSS version 17.0. Independent sample t-test/ Mann-Whitney U-test were applied.

\section{Result}

Total numbers of patients registered during this period were 84 . The conditions causing precocious puberty were central precocious puberty (36.5\%), peripheral precocious puberty $(38.8 \%)$, premature pubarche $(10.6 \%)$ and premature thelarche (14.1\%). In central precocious puberty 26 were female and 5 were male. The causes identified in them were idiopathic $(67.74 \%)$, hypothalamic hamartoma (12.90\%), craniopharagioma (9.67\%), arachnoid cyst (3.22\%), hypothalamic astrocytoma (3.2\%), hydrocephalus (3.2\%). In peripheral precocious puberty21 were male and 12 were female. Congenital adrenal hyperplasia (81.8\%), adenocarcinoma $(9.1 \%)$, ovarian teratoma $(6.1 \%)$ and Mc Cune Albright syndrome (3\%) were diagnosed in them. There was difference in the age of onset of puberty of

National Institute of Child Health, Karachi, Pakistan central precocious puberty $3(2-6)$ versus peripheral precocious puberty $5.25(3.62-7.0)$. Central precocious puberty children showed higher height SDS, weight SDS, FSH, LH than peripheral precocious puberty.

\section{Conclusion}

Peripheral precocious puberty is more common than central precocious puberty. Height SDS, weight SDS, FSH, LH was higher in central precocious puberty versus peripheral precocious puberty.

Published: 3 October 2013

doi:10.1186/1687-9856-2013-S1-P65

Cite this article as: Atta et al:: Precocious puberty in children.

International Journal of Pediatric Endocrinology 2013 2013(Suppl 1):P65.
Submit your next manuscript to BioMed Central and take full advantage of:

- Convenient online submission

- Thorough peer review

- No space constraints or color figure charges

- Immediate publication on acceptance

- Inclusion in PubMed, CAS, Scopus and Google Scholar

- Research which is freely available for redistribution
C Bïomed Central (c) 2013 Atta et al; licensee BioMed Central Ltd. This is an Open Access article distributed under the terms of the Creative Commons Attribution License (http://creativecommons.org/licenses/by/2.0), which permits unrestricted use, distribution, and reproduction in any medium, provided the original work is properly cited. 